\title{
Ventilation of the Very Immature Lung In Utero Induces Injury and BPD-Like Changes in Lung Structure in Fetal Sheep
}

\author{
BETH J. ALLISON, KELLY J. CROSSLEY, SHARON J. FLECKNOE, PETER G. DAVIS, COLIN J. MORLEY, \\ RICHARD HARDING, AND STUART B. HOOPER
}

\author{
Department of Physiology [B.J.A., K.J.C., S.J.F., S.B.H.], Department of Anatomy and Developmental Biology [R.H.], Monash University, \\ Victoria 3800, Australia; Neonatal Services [P.G.D., C.J.M.], Royal Women's Hospital, Carlton, Victoria 3035, Australia
}

\begin{abstract}
Preterm infants are at high risk of developing ventilator-induced lung injury (VILI), which contributes to bronchopulmonary dysplasia. To investigate causes of VILI, we have developed an animal model of in utero ventilation (IUV). Our aim was to characterize the effects of IUV on the very immature lung, in the absence of nonventilatory factors that could contribute to lung pathology. Fetal sheep were ventilated in utero at $110 \mathrm{~d}$ gestation for 1 , 6 , or $12 \mathrm{~h}$ (two groups; $n=5$ each). Lung tissue was collected at $12 \mathrm{~h}$ after initiating IUV in the 1,6 , and one $12 \mathrm{~h}$ IUV groups. Lung liquid was replaced in the second $12 \mathrm{~h}$ IUV group and tissues collected at $117 \mathrm{~d}$. Operated, nonventilated 110 and $117 \mathrm{~d}$ fetuses were controls. IUV reduced secondary septal crest densities, simplified distal airsacs, caused abnormal collagen and elastin deposition, and stimulated myofibroblast differentiation and cellular proliferation. IUV causes VILI in very immature lungs in the absence of other complicating factors and reproduces bronchopulmonary dysplasia -like changes in lung morphology. IUV offers a novel method for dissociating VILI from other iatrogenic factors that could contribute to altered lung development caused by VILI. (Pediatr Res 64: 387-392, 2008)
\end{abstract}

$\mathrm{V}$ ery preterm infants $(<30 \mathrm{wk}$ gestation) commonly require resuscitation and assisted ventilation that are closely associated with lung injury (1). Many of these infants $(\sim 30 \%)$ subsequently develop bronchopulmonary dysplasia (BPD), which is characterized by pathologic changes in lung structure, including larger more simplified alveoli, abnormal capillary growth and elastin deposition $(2,3)$, nonuniform inflation, fibrosis, and edema $(4,5)$.

The causes of neonatal lung injury are complex and not fully understood. Animal models used previously to investigate the causes include prolonged ventilation of prematurely delivered baboons (6) and lambs (5). However, it was necessary to ventilate the animals for hours or days to maintain their viability while allowing sufficient time for pathologic changes to develop. During this time, other interventions can be required to ensure survival, including temperature control, higher inspired oxygen levels and ventilation pressures as well as the administration of surfactant, i.v. fluids, nutrition and drugs. As a result, it is difficult to separate the factors causing ventilator-induced lung injury (VILI) from the additional treatments required for survival. To avoid these problems, we

Received January 2, 2008; accepted May 15, 2008.

Correspondence: Beth Allison, Department of Physiology, Monash University, Victoria 3800, Australia; e-mail: beth.allison@med.monash.edu.au

Supported by grants from the Australian NH\&MRC and Monash University. have developed a model of VILI, which involves ventilation of very immature fetal lambs in utero.

Previously in utero ventilation (IUV) was used to study birth-related changes in cardiopulmonary physiology in late gestation, but not VILI (7-9). IUV has numerous advantages as a model for VILI as the fetus remains on placental support and is not dependent upon ventilation for gas exchange. Thus, individual ventilation parameters can be examined independently and the fetus can remain alive in utero for extended periods following IUV without the need for additional treatments. Importantly, the effects of ventilation can also be studied at an earlier developmental stage in fetal sheep than is possible ex utero. Our objective was to characterize the effects of IUV in very preterm sheep on lung structure, particularly after an extended period (7 d) of in utero development after IUV. We hypothesized that ventilating fetal sheep in utero, using a protocol likely to cause VILI, would induce changes in lung structure that are BPD-like and that the pathology would persist, but change with time.

\section{MATERIALS AND METHODS}

Fetal surgery. All experimental procedures were approved by the Monash University Animal Ethics Committee. Under general anesthesia (1.5\% halothane in $\mathrm{O}_{2}$ ), aseptic surgery was performed on 30 Border-Leicester $\times$ Merino ewes at $105 \mathrm{~d}$ gestation (term is $\sim 147 \mathrm{~d}$ ). During surgery, an endotracheal tube was inserted and connected, via a Y-piece, to two large bore, salinefilled, ventilation tubes (ID $9.5 \mathrm{~mm}$, OD $14.3 \mathrm{~mm}$ ). A saline-filled catheter (ID $3.2 \mathrm{~mm}$, OD $6.4 \mathrm{~mm}$ ) was inserted into the upper trachea and connected to a saline-filled ventilation tube to create an exteriorized tracheal loop, allowing the normal flow of lung liquid. Polyvinyl catheters were implanted into the fetal carotid artery, jugular vein, and amniotic sac and exteriorized via the ewe's flank. Ewes and fetuses were allowed $5 \mathrm{~d}$ recovery in room air after surgery. Fetal arterial blood $\mathrm{PaO}_{2}, \mathrm{PaCO}_{2}, \mathrm{pH}$, and $\mathrm{SaO}_{2}$ were measured every second day to assess fetal wellbeing.

Experimental protocol. Before IUV, ventilation tubes were disconnected from the upper tracheal catheter and the liquid drained into a sterile bag before the tubes were connected to a neonatal ventilator (Draeger $8000+$ ). Fetuses were divided into six groups ( $\mathrm{n}=5$ each): (1) $1 \mathrm{~h}$ of IUV followed by $11 \mathrm{~h}$ of lung liquid replacement (LR) (1 h IUV); (2) $6 \mathrm{~h}$ of IUV followed by $6 \mathrm{~h}$ of LR (6 h IUV); (3) $12 \mathrm{~h}$ of IUV (12 h IUV); (4) $12 \mathrm{~h}$ of IUV plus $7 \mathrm{~d}$ of LR ( $12 \mathrm{~h}$ IUV $+7 \mathrm{~d})$; (5) operated age-matched controls at $110 \mathrm{~d}$ (110 d control); and (6) operated age-matched controls at $117 \mathrm{~d}$ (117 d control). In groups 1

Abbreviations: 1 h IUV, $1 \mathrm{~h}$ of in utero ventilation with $11 \mathrm{~h}$ of lung liquid replacement; 12 h IUV, 12 h of in utero ventilation; 12 h IUV $+\mathbf{7}$ d, 12 h of in utero ventilation with $7 \mathrm{~d}$ of lung liquid replacement; $6 \mathbf{~ h ~ I U V , ~} 6 \mathrm{~h}$ of in utero ventilation with $6 \mathrm{~h}$ of lung liquid replacement; BPD, Bronchopulmonary Dysplasia; IUV, In utero ventilation; LR, Lung liquid replacement; VILI, Ventilation-induced lung injury; $\boldsymbol{\alpha S M A}$, Alpha smooth muscle actin 
and 2, lung liquid was replaced after ventilation so that comparisons between groups could be made at $12 \mathrm{~h}$ after initiating ventilation. In group 4, lung liquid was replaced for $7 \mathrm{~d}$ to determine whether LR mitigated any changes caused by $12 \mathrm{~h}$ of IUV.

Fetuses were ventilated in utero (groups 1-4) at $110 \mathrm{~d}$ gestation using room air, a peak inspiratory pressure of $40 \mathrm{~cm} \mathrm{H}_{2} \mathrm{O}$, a positive end-expiratory pressure of $4 \mathrm{~cm} \mathrm{H} \mathrm{H}_{2} \mathrm{O}$, an inspiratory flow of $15 \mathrm{~L} / \mathrm{min}$ and a rate of 65 breaths/min. Our goal was to ventilate using a strategy that is physiologic, but would likely cause injury to these immature lungs. As the flow sensor could not function in utero, the tidal volumes were assessed, using the same ventilation settings, in separate fetuses $(n=3)$ whose heads were exteriorized, but their bodies remained in utero. In these fetuses, the tidal volume was 3-5 $\mathrm{mL} / \mathrm{kg}$ during the $1 \mathrm{~h}$ ventilation period. Arterial and amniotic sac pressures were measured using pressure transducers and recorded digitally (Powerlab, ADI, Australia). Arterial blood gases were measured hourly. Following ventilation, 12 h IUV fetuses (group 3) were humanely killed, whereas fetuses in groups 1,2, and 4 had their lung liquid replaced, refilling both the lung and ventilation tubes, and the upper tracheal catheter was reconnected, restoring normal lung liquid flow. These fetuses were killed following the appropriate

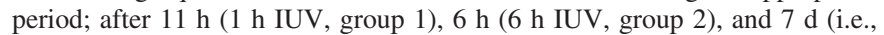
at $117 \mathrm{~d} \mathrm{GA} ; 12 \mathrm{~h} \mathrm{IUV}+7 \mathrm{~d}$, group 4$)$.

Tissue collection. The fetal lungs were drained of liquid (groups 1 and 2, 4-6) and the ewe and fetus humanely killed with sodium pentobarbitone (130 $\mathrm{mg} / \mathrm{kg}$ i.v.). The fetal lungs were removed, weighed, the left bronchus ligated and portions of the left lung snap frozen and stored at $-70^{\circ} \mathrm{C}$. The right lung was fixed at $20 \mathrm{~cm} \mathrm{H}_{2} \mathrm{O}$ via the trachea with $4 \%$ paraformaldehyde, postfixed in Zamboni's fixative and processed for light microscopy; $20 \mathrm{~cm} \mathrm{H}_{2} \mathrm{O}$ inflates the fetal lungs to a luminal volume similar to that observed in vivo (10). Lung tissue DNA concentrations were measured (11). Percentage water content of lung tissue was determined by drying tissue samples, of known weight, in a $70^{\circ} \mathrm{C}$ oven until no change in weight was detected for three consecutive days. The difference between wet and dry tissues weight was used to calculate water content.

Histologic analysis of lung tissue injury. The right lung was separated into cranial, middle, and caudal lobes and cut into $5 \mathrm{~mm}$ slices. Every second slice, from each lobe, was divided into three. Six pieces were chosen at random (using a random number table) from each lobe, cut into $2 \mathrm{~cm}^{2}$ sections ( $5 \mathrm{~mm}$ thick) and embedded in paraffin. Blocks were randomly selected from each lobe and sectioned at $5 \mu \mathrm{m}$; the sections were incubated at $60^{\circ} \mathrm{C}(2 \mathrm{~h})$, deparaffinized, rehydrated, and washed in phosphate buffered saline (PBS).

Different sections were stained with hematoxylin and eosin, Hart's resorcinfuschin stain to identify elastin (12), and with Gordon and Sweet reticulum stain to identify collagen. Immunohistochemistry was used to identify proliferating cells (Ki67) and myofibroblasts (alpha smooth muscle actin; $\alpha \mathrm{SMA}$ ). The percentage of lung occupied by tissue was measured by image analysis, which was validated using a point counting technique (13), whereas secondary septal crest densities were measured using a point-counting technique and expressed in relation to tissue area; five sections and three fields of view per section were used for these analyses. Elastin, collagen and $\alpha$ SMA staining density was measured by image analysis (ImagePro plus) using five random fields of view per section of the lung; assessed by single observer [B.J.A.] blinded to the experimental group. For each field of view, staining density was adjusted for tissue area. For proliferating cells, Ki67 labeled cells were counted and expressed as a proportion of the total number of cells to determine a labeling index.

Immunohistochemistry. Tissue sections were boiled in sodium citrate (0.01M, pH 6.0), washed in PBS $(2 \times 5 \mathrm{~min})$ and incubated in hydrogen peroxide (3\%, $5 \mathrm{~min})$. The sections were rinsed in water, washed in PBS and incubated in blocking/permeabilization buffer (3\% normal goat serum; $0.1 \%$ TritonX-100 in PBS). Sections were incubated with primary antibody (antihuman Ki67; anti-human $\alpha$ SMA; Dakocytomation, Denmark) for $90 \mathrm{~min}$ (RT), washed in PBS (with $0.1 \%$ Tween-20) for 5 min $(\times 3)$ and incubated with biotinylated secondary antibody (anti-mouse Biotinylated Ab; Vector laboratories, Burlingame, CA) in PBS for $1 \mathrm{~h}$. Sections were again washed in PBS/0.1\% Tween-20 for $5 \mathrm{~min}(\times 3)$ and the biotinylated secondary antibody detected (Vectastain ABC; Vector laboratories). Sections were washed, dehydrated, mounted, and viewed using light microscopy.

Statistical analysis. Values are expressed as mean \pm SEM. Statistical comparisons between treatments in histologic observations were made with a nested analysis of variance; significance between individual values was determined using a least square difference (LSD) posthoc test. Differences in tissue DNA concentrations were determined using a one-way analysis of variance and considered statistically significant if $\mathrm{p}<0.05$.

\section{RESULTS}

Fetal arterial blood gas status. All fetuses had normal blood gas and acid-base status throughout these experiments. Fetal blood gases did not change from preexperimental values throughout the IUV period and were similar to unventilated controls fetuses at $7 \mathrm{~d}$ postIUV (data not shown).

General morphology. At $110 \mathrm{~d}$ gestation, the distal lung of fetal sheep is characterized by narrow inter-saccular walls and few small secondary septal crests. $1 \mathrm{~h}$ IUV and $6 \mathrm{~h}$ IUV fetuses had regions of differing alveolar wall thickness and more simplified distal airways compared with controls (Fig. 1A). In $12 \mathrm{~h}$ IUV fetuses, the distal lung contained numerous atelectatic and/or hypercellular regions whereas other regions were over-distended and dysmorphic. Similarly, the lungs of $12 \mathrm{~h} \mathrm{IUV}+7 \mathrm{~d}$ fetuses had atelectatic or hypercellular regions and enlarged alveolar sacs (Fig. 1A). The lungs of IUV fetuses were characterized by enlarged connective tissue septa (Fig. 1B), normally comprised of collagen fibers, but also contained red blood cells, indicating hemorrhage. The percentage of space occupied by peri-alveolar/saccular tissue in $110 \mathrm{~d}$ control fetuses $(49.8 \pm 2.2 \%)$ was similar to both $1 \mathrm{~h} \mathrm{IUV}$ $(48.1 \pm 5.1 \%)$ and $6 \mathrm{~h}$ IUV $(45.8 \pm 4.6 \%)$ fetuses, but was less $(\mathrm{p}<0.01)$ than $12 \mathrm{~h} \mathrm{IUV}$ fetuses $(64.5 \pm 8.4 \%)$ (Fig. 1$)$. In $12 \mathrm{~h}$ IUV $+7 \mathrm{~d}$ fetuses, the percentage of space occupied by tissue $(43.6 \pm 5.3 \%)$ increased compared with $117 \mathrm{~d}$ controls $(35.2 \pm 3.9 \% ; \mathrm{p}<0.01)$. As the percent water content of lung tissue was not increased ( $1 \mathrm{~h} \mathrm{IUV}, 88.9 \pm$

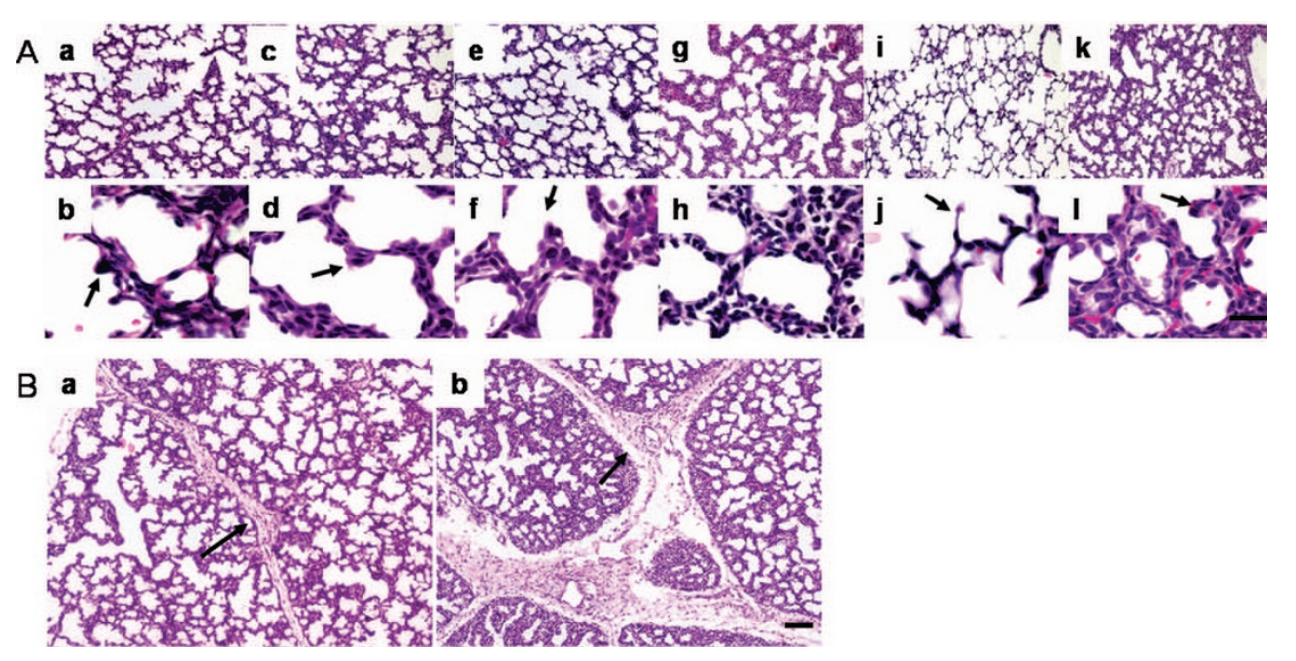

Fig. 1. (A) Distal airsacs of control fetuses at $110 \mathrm{~d}(\mathrm{a}$ and $\mathrm{b})$ and $117 \mathrm{~d}$ ( $\mathrm{i}$ and $\mathrm{j}$ ) of gestation; and fetuses exposed to $1 \mathrm{~h}$ IUV(c and d), $6 \mathrm{~h} \mathrm{IUV} \mathrm{(e} \mathrm{and} \mathrm{f)} \mathrm{and} 12 \mathrm{~h}$ of IUV ( $\mathrm{g}$ and $\mathrm{h}$ ) and $12 \mathrm{~h}$ of IUV, plus $7 \mathrm{~d}$ of LR (k and 1$)$ at high $(\times 1000 ; \mathrm{b}, \mathrm{d}, \mathrm{f}, \mathrm{h}$, $\mathrm{j}, 1$ bar $=10 \mu \mathrm{m})$ and low $(\times 200 ; \mathrm{a}, \mathrm{c}, \mathrm{e}$, $\mathrm{g}, \mathrm{i}, \mathrm{k}$ bar $=50 \mu \mathrm{m})$ magnification. Sections were stained with hematoxylin and eosin. Compared with controls, IUV fetuses have regions of nonuniform inflation, simplified airsacs, and hypercellularity. (B) Sections demonstrating enlarged connective tissue septa in IUV fetuses. Bar = $100 \mu \mathrm{m}$. 
$0.7 \% ; 6$ h IUV, $88.3 \pm 1.2 \% ; 12$ h IUV, $86.3 \pm 0.6 \%)$ compared with controls $(88.9 \pm 0.5 \%)$, edema is not responsible for the greater relative tissue areas.

Secondary septal crest densities. In 110 d control fetuses, $6.8 \pm 1.3 \%$ of lung tissue was occupied by secondary crests compared with $5.4 \pm 1.3 \%$ in $1 \mathrm{~h} \mathrm{IUV}$ fetuses and $1.3 \pm 0.5 \%$ in $12 \mathrm{~h}$ IUV fetuses $(\mathrm{p}<0.05)$ (Fig. 2). In $12 \mathrm{~h}$ IUV $+7 \mathrm{~d}$ fetuses, secondary septal crest density $(4.6 \pm 1.2 \%)$ was also less than both $110 \mathrm{~d}$ and $117 \mathrm{~d}$ controls $(8.1 \pm 0.3 \%)$. The secondary septal crests appeared thicker and shorter in IUV fetuses compared with age-matched controls (Fig. 1A).

Distal lung hypercellularity. The DNA concentration of lung tissue increased from $4.8 \pm 0.2 \mathrm{mg} / \mathrm{g}$ in $110 \mathrm{~d}$ controls to $6.4 \pm 0.3 \mathrm{mg} / \mathrm{g}$ and $7.0 \pm 0.2 \mathrm{mg} / \mathrm{g}$ in $1 \mathrm{~h} \mathrm{IUV}$ and $6 \mathrm{~h} \mathrm{IUV}$ fetuses, respectively (Fig. 3). Similarly, the lung DNA concentration tended to be greater than control $(5.8 \pm 0.5 \mathrm{mg} / \mathrm{g} \mathrm{v}$

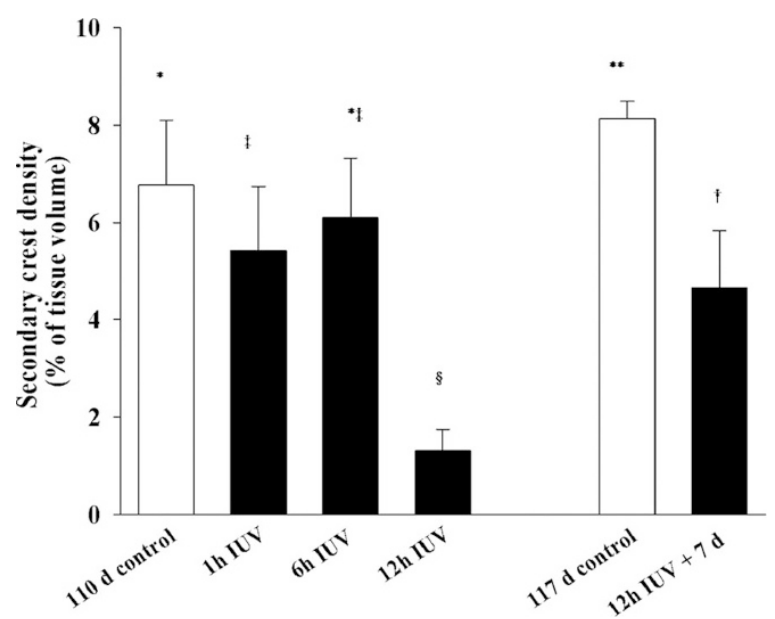

Fig. 2. Secondary septal crests density in $110 \mathrm{~d}(n=5)$ and $117 \mathrm{~d}(n=4)$ control fetuses and fetuses exposed to $1 \mathrm{~h} \mathrm{IUV}, 6 \mathrm{~h}$ IUV and $12 \mathrm{~h} \mathrm{IUV}$ and $12 \mathrm{~h}$ of IUV followed by $7 \mathrm{~d}$ of lung LR (12 h IUV $+7 \mathrm{~d} ; n=5$ each). Different symbols indicate values that are significantly different from each other $(p<0.05)$.

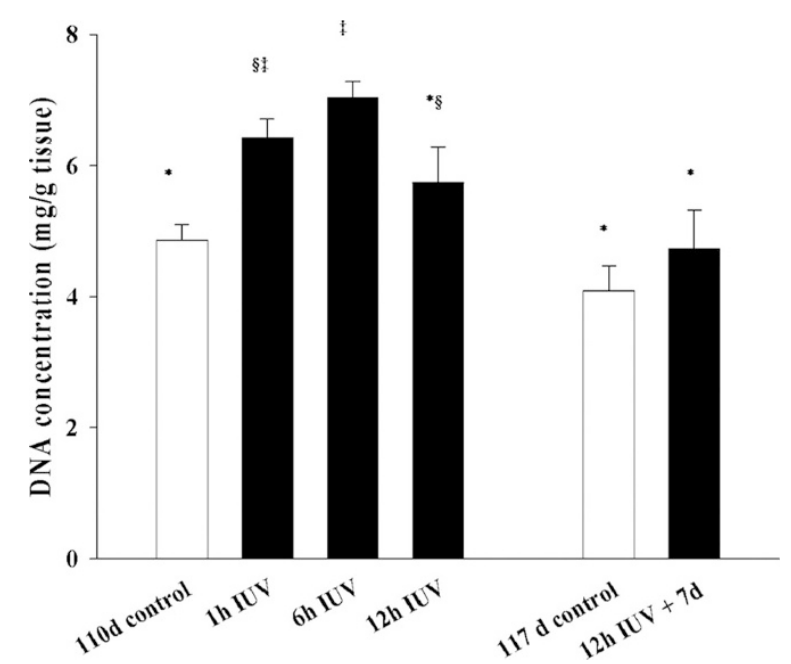

Fig. 3. Lung DNA concentration $(\mathrm{mg} / \mathrm{g}$ tissue; mean $\pm \mathrm{SEM})$ in $110 \mathrm{~d}(n=$ 5) and $117 \mathrm{~d}(n=4)$ control fetuses and fetuses exposed to 1, 6 and $12 \mathrm{~h} \mathrm{IUV}$ and $12 \mathrm{~h}$ of IUV followed by $7 \mathrm{~d}$ of lung liquid replacement $(12 \mathrm{~h} \mathrm{IUV}+7 \mathrm{~d}$; $n=5$ each). Different symbols indicate values that are significantly different from each other $(p<0.05)$.
$4.8 \pm 0.2 \mathrm{mg} / \mathrm{g})$ in $12 \mathrm{~h} \mathrm{IUV}$ fetuses, but was not statistically significant $(\mathrm{p}=0.09)$. In $12 \mathrm{~h}$ IUV $+7 \mathrm{~d}$ fetuses, the lung DNA concentration $(4.7 \pm 0.6 \mathrm{mg} / \mathrm{g})$ also tended to be greater, but was not different from $117 \mathrm{~d}$ controls $(4.0 \pm 0.4 \mathrm{mg} / \mathrm{g})$. The percentage of proliferating distal lung cells increased from $6.0 \pm 0.9 \%$ in $110 \mathrm{~d}$ control fetuses to $12.7 \pm 1.5 \%$ and $9.1 \pm 1.0 \%$ in $1 \mathrm{~h} \mathrm{IUV}$ and $6 \mathrm{~h}$ IUV fetuses, respectively (Fig. 4A). Although, the percentage of Ki67 labeled cells was similar to control in $12 \mathrm{~h}$ IUV fetuses $(6.7 \pm 1.2 \%)$, they were higher in $12 \mathrm{~h}$ IUV $+7 \mathrm{~d}$ fetuses $(7.8 \pm 2.2 \%)$ compared with $117 \mathrm{~d}$ controls $(0.7 \pm 0.5 \%)$ (Fig. $4 \mathrm{~A})$. In IUV fetuses, clumps of dividing cells (Ki67 positive) were commonly observed (Fig. 4B).

Elastin. In $110 \mathrm{~d}$ control fetuses, elastin was predominantly located at the tips of developing secondary septa, although some staining also occurred in saccule walls (Fig. 5A). IUV resulted in greater staining around the base of saccule walls and less in secondary septal crests, particularly as there were fewer crests (Fig. 2). Although the density of elastin staining in peri-saccular/alveolar regions was similar in control fetuses $(1.8 \pm 0.2 \%), 1 \mathrm{~h}$ IUV $(1.2 \pm 0.3 \%)$ and $6 \mathrm{~h}$ IUV fetuses $(1.8 \pm 0.2 \%)$, it was increased in $12 \mathrm{~h}$ IUV fetuses $(2.9 \pm$ $0.5 \%)$. Abnormal and increased elastin staining also occurred in $12 \mathrm{~h} \mathrm{IUV}+7 \mathrm{~d}$ fetuses $(3.5 \pm 0.5 \%)$ compared with $117 \mathrm{~d}$ controls $(1.3 \pm 0.1 \%$; $<<0.05)$ (Fig. 5B).

Collagen. In IUV fetuses, the collagen fibers surrounding saccule walls appeared thicker and numerous finer fibers formed a mesh-like structure, which interconnected with the larger fibers. This fine mesh-like structure was barely evident in control fetuses (Fig. 6A). In all $12 \mathrm{~h}$ IUV $+7 \mathrm{~d}$ fetuses, collagen deposition appeared disorganized with the finer meshwork of fibers remaining prevalent. The density of collagen staining was similar in $110 \mathrm{~d}$ control fetuses $(20.5 \pm$ $0.7 \%)$ and $1 \mathrm{~h} \mathrm{IUV}(20.4 \pm 1.5 \%)$ and $6 \mathrm{~h} \mathrm{IUV}(20.2 \pm 1.2 \%)$ fetuses but was increased in $12 \mathrm{~h}$ IUV fetuses $(27.5 \pm 2.6 \%)$ (Fig. 6B). In $12 \mathrm{~h} \mathrm{IUV}+7 \mathrm{~d}$ fetuses, the density of collagen staining $(27.7 \pm 0.4 \%)$ was similar to $117 \mathrm{~d}$ controls $(27.3 \pm$ $0.9 \%$ ) although the pattern of deposition was different.

Myofibroblast differentiation. Compared with $110 \mathrm{~d}$ controls $(11.4 \pm 1.6 \%), \alpha \mathrm{SMA}$ staining in the distal lung was greater in $1 \mathrm{~h} \mathrm{IUV}(24.3 \pm 1.8 \%)$ and $6 \mathrm{~h}$ IUV $(26.5 \pm 1.4 \%)$ fetuses $(\mathrm{p}<0.001)$ (Fig. 7A). Although $\alpha$ SMA staining tended to be elevated in $12 \mathrm{~h}$ IUV fetuses $(16.3 \pm 2.6 \%)$, it was not different from $110 \mathrm{~d}$ control fetuses. However, $\alpha$ SMA staining was elevated in $12 \mathrm{~h}$ IUV $+7 \mathrm{~d}$ fetuses $(19.1 \pm$ $3.2 \%$ ) compared with $117 \mathrm{~d}$ controls (13.6 $\pm 1.5 \%)$ (Fig. 7B).

\section{DISCUSSION}

Despite considerable investigation into factors causing VILI in very preterm infants, the primary mechanisms are unknown (14). We have developed a fetal animal model to investigate the specific causes of VILI in the absence of potentially confounding factors. We demonstrate that IUV of very immature fetal sheep, in the presence of normal nutrition, blood gases and a sterile environment, causes VILI, and can induce BPD-like changes in lung morphology. These occurred in response to short periods of ventilation $(1,6$, or $12 \mathrm{~h})$ and 

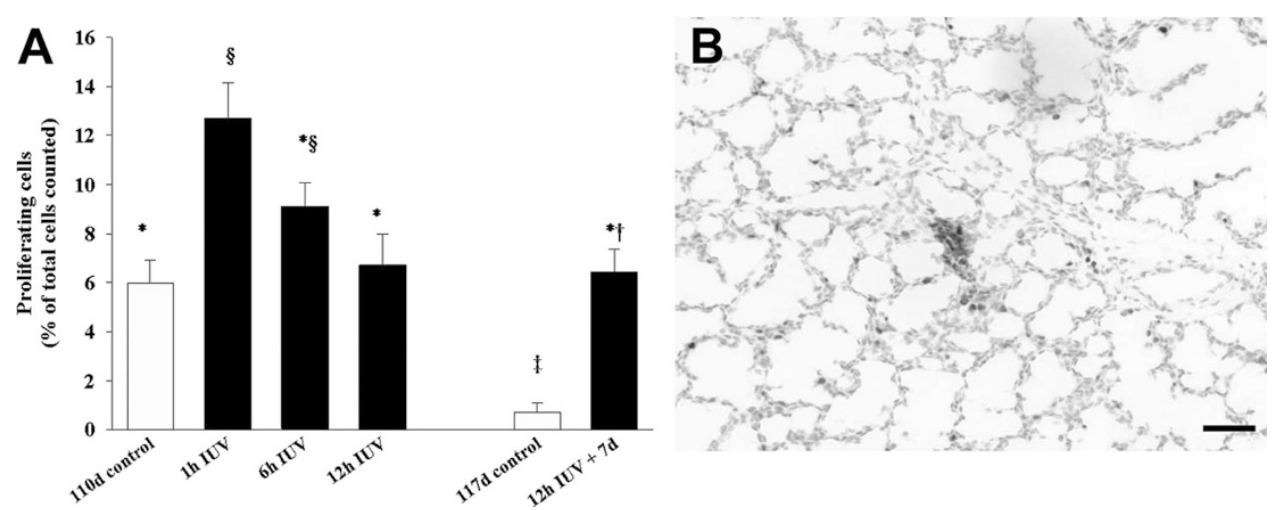

Fig. 4. (A) Labeling index for Ki67 stained cells (marker of cell proliferation), expressed as a percentage of total cells in $110 \mathrm{~d}(n=5)$ and $117 \mathrm{~d}(n=4)$ control fetuses $(\square)$ and fetuses exposed to 1,6 , and $12 \mathrm{~h} \mathrm{IUV}$ and $12 \mathrm{~h}$ of IUV followed by $7 \mathrm{~d}$ of lung LR (12 h IUV $+7 \mathrm{~d} ; n=5$ each) (ם). Different symbols indicate values that are significantly different from each other $(p<0.05)$. (B) Cluster of Ki67 positive cells commonly observed within the lung of IUV fetuses. Magnification $\times 200 ;$ Bar $=50 \mu \mathrm{m}$.
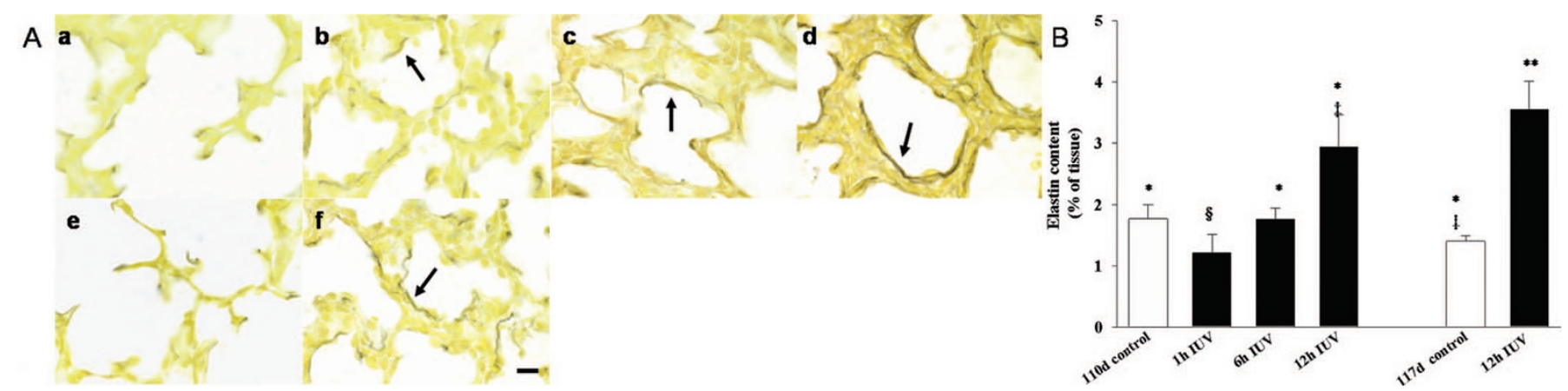

Fig. 5. (A) Elastin (stained dark) fibers in distal lung of $110 \mathrm{~d}(\mathrm{a} ; n=5)$ and $117 \mathrm{~d}(\mathrm{e} ; n=4)$ control fetuses and fetuses exposed to $1 \mathrm{~h}$ IUV (b), $6 \mathrm{~h}$ IUV (c) and $12 \mathrm{~h} \mathrm{IUV} \mathrm{(d)} \mathrm{and} 12 \mathrm{~h}$ of IUV followed by $7 \mathrm{~d}$ of lung LR (12 h IUV $+7 \mathrm{~d}$ f; $n=5$ each). Magnification $\times 1000$; Bar $=10 \mu \mathrm{m}(B)$ Elastin staining density (\% of lung tissue area) in $110 \mathrm{~d}$ and $117 \mathrm{~d}$ control fetuses $(\square)$ and fetuses exposed to 1,6 and $12 \mathrm{~h}$ of IUV and $12 \mathrm{~h}$ of IUV followed by $7 \mathrm{~d}$ of lung LR (匹). Different symbols indicate values that are significantly different from each other $(p<0.05)$.
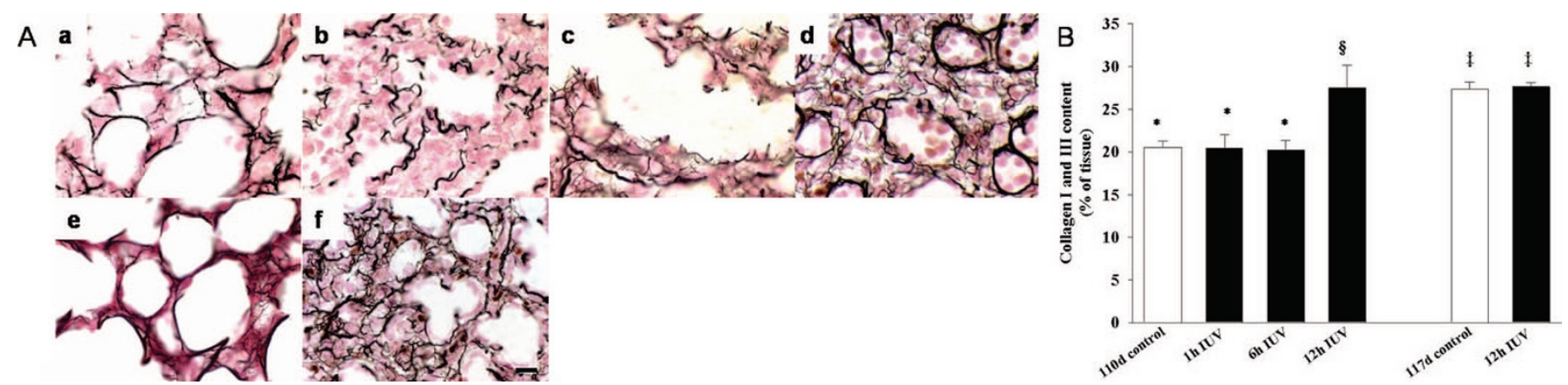

Fig. 6. (A) Collagen (stained black) fibers in lung tissue of $110 \mathrm{~d}(\mathrm{a} ; n=5)$ and $117 \mathrm{~d}(\mathrm{e} ; n=4)$ control fetuses and fetuses exposed to $1 \mathrm{~h}$ IUV (b), $6 \mathrm{~h}$ IUV (c) and $12 \mathrm{~h} \mathrm{IUV} \mathrm{(d)} \mathrm{and} 12 \mathrm{~h}$ of IUV followed by $7 \mathrm{~d}$ of lung LR (12 h IUV $+7 \mathrm{~d} \mathrm{f} ; n=5$ each). Magnification $\times 1000$; Bar $=10 \mu \mathrm{m}(B)$ Collagen staining density (\% of lung tissue area) in 110 and $117 \mathrm{~d}$ control fetuses $(\square)$ as well as fetuses exposed to 1,6 , and $12 \mathrm{~h}$ of IUV and $12 \mathrm{~h}$ of IUV followed by $7 \mathrm{~d}$ of lung LR (ם). Different symbols indicate values that are significantly different from each other $(p<0.05)$.
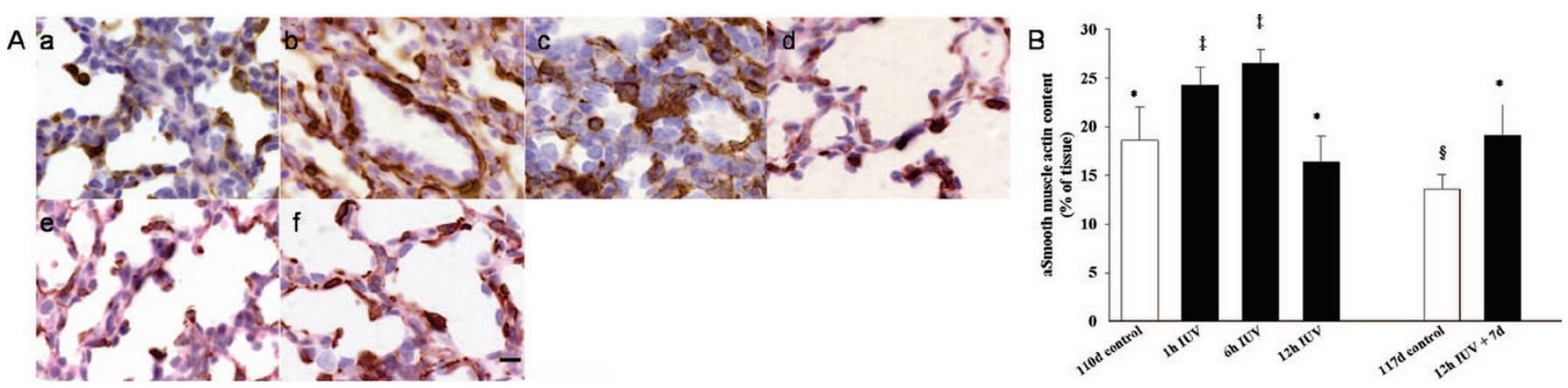

Fig. 7. (A) Myofibroblasts, stained for alpha smooth muscle actin ( $\alpha$ SMA; brown), in lung tissue of $110 \mathrm{~d}(\mathrm{a} ; n=5)$ and $117 \mathrm{~d}(\mathrm{e} ; n=4)$ control fetuses and fetuses exposed to $1 \mathrm{~h}$ IUV (b), $6 \mathrm{~h}$ IUV (c) and $12 \mathrm{~h} \mathrm{IUV}(d)$ and $12 \mathrm{~h}$ of IUV followed by $7 \mathrm{~d}$ of lung LR (12 h IUV $+7 \mathrm{~d} \mathrm{f} ; n=5$ each). Magnification $\times 1000$; Bar $=10 \mu \mathrm{m}(B) \alpha$ SMA staining density (\% of lung tissue area) in 110 and $117 \mathrm{~d}$ control fetuses $(\square)$ as well as fetuses exposed to 1,6 , and $12 \mathrm{~h}$ of IUV and $12 \mathrm{~h}$ of IUV followed by $7 \mathrm{~d}$ of lung LR ( $\square$ ). Different symbols indicate values that are significantly different from each other $(p<0.05)$. 
persisted for at least $7 \mathrm{~d}$ in the absence of continued ventilation or additional treatments. This is the first study to ventilate fetal sheep at a stage of development (mid-late canalicular stage) when distal lung structure and alveolar epithelial cell development resembles that of very preterm human infants ( $<28$ wk). Furthermore, our study shows that pathologic changes in lung structure, which are BPD-like, can be induced by only a few hours of ventilation in very immature lungs, in the absence of other iatrogenic factors.

In utero ventilation has been performed previously in late gestation sheep to study birth-related changes in cardiopulmonary physiology. These experiments were short in duration, the umbilical cord was obstructed and the lungs were not examined for VILI (7-9). We chose to perform IUV in fetal sheep at $110 \mathrm{~d}$ when the distal air-spaces have few alveoli, are mostly comprised of saccules and the epithelial cells are mainly undifferentiated (15), because this structure resembles a human lung at $\sim 26 \mathrm{wk}$ gestation. It is not possible to successfully ventilate fetal sheep ex utero at $110 \mathrm{~d}$ and maintain them in a healthy state for prolonged periods. With IUV, the placental circulation remained intact and so pulmonary gas exchange and additional treatments were not required to maintain fetal viability during and after ventilation. Thus, this technique allowed time for pathologic changes to occur, which may take many hours or days, without the need for continued ventilation or other interventions that may contribute to further injury. Although the changes in lung morphology we observed appear slightly more severe than those now commonly associated with BPD (3), this was expected as we ventilated fetuses to cause injury.

The increase in relative tissue space in IUV fetuses is consistent with changes observed in other models of BPD (6) and are unlikely to result from atelectasis or edema. We believe that the increase in relative tissue space in IUV fetuses resulted, in part, from hypercellularity caused by proliferation of interstitial fibroblasts. This suggestion is consistent with the increase in lung DNA concentration and an increase in the number of proliferating cells within the distal lung parenchyma. Just $1 \mathrm{~h}$ of IUV induced a large increase in cellular proliferation, which remained elevated $7 \mathrm{~d}$ later. Many of the proliferating cells in IUV fetuses occurred in small clumps (Fig. 7B) and were not evenly distributed as observed in control fetuses. It is possible that clumps of proliferating cells reflect sites of inflammatory cell recruitment that release growth factors/cytokines that stimulate localized cell proliferation and septal wall thickening. As increased cell proliferation alone is unlikely to account for the increase in DNA concentration after IUV, the recruitment of circulating inflammatory cells in response to injury must be a contributing factor.

Simplification of distal airsacs is a common feature of BPD and is thought to result from abnormal elastin and collagen deposition $(5,16)$. We observed reduced septal crest densities in all IUV fetuses, even in the $1 \mathrm{~h}$ IUV group, with the greatest reduction in the $12 \mathrm{~h}$ IUV group. As this reduction occurred within $12 \mathrm{~h}$, it could not have resulted from a reduction in the formation of new crests, but likely results from the reabsorption of preexisting secondary septal crests. Thus, ventilationinduced reabsorption of immature secondary septal crests may contribute to the reduction in alveolar formation and airsac simplification observed in BPD and may partly explain the commonly observed altered pattern of elastin deposition (17).

Elastin deposition is critical for lung development and postnatal lung function because it is required for normal airway branching, alveolar development and contributes to the lung's elastic recoil (18). During alveolar development $(18,19)$ elastin is primarily deposited at the tips of developing septal crests whereas VILI increases and alters the spatial pattern of elastin deposition $(17,20,21)$. We observed increased and abnormal spatial patterns of elastin deposition in all IUV fetuses. This is consistent with the suggestion that VILI destroys immature secondary septal crests, causing them to flatten and become part of the primary septal wall, leading to larger more simplified distal airways. As a result, the elastin bundles normally deposited at the tips of secondary septal crests become part of the primary septal wall giving the appearance of abnormal deposition. Increased and abnormal elastin deposition was also detected in $12 \mathrm{~h}$ IUV $+7 \mathrm{~d}$ fetuses indicating that the changes persist and may be permanent.

The fibrillar collagens play a critical role in primary septation (16) as well as providing a mechanical scaffolding that supports the airways during respiration (22). Increased and abnormal spatial deposition of collagen I and III occurs in BPD and may last from weeks to months after injury (23-25), leading to tissue remodeling and changes in lung mechanics (16). Although an abnormal pattern of collagen deposition was observed in all IUV fetuses, an increase in collagen deposition was only detected in $12 \mathrm{~h}$ IUV fetuses. Thus, part of the altered pattern of collagen deposition may also result from mechanical disruption of the tissue. The interlobular connective tissue septa of the lung consist of collagen fibers that extend in from the visceral pleura and out from major blood vessels and airways (26). They mechanically couple smaller airways and blood vessels with the outer pleural membrane, thereby greatly improving the transmission of force between the visceral pleura and small airways located deep within the lung. The enlargement of these fiber tracts in IUV fetuses did not appear to result from increased collagen deposition. As red blood cells were commonly observed within these enlarged fiber tracts, hemorrhage and or air leaks, followed by edema, resulting from VILI are likely causes.

Myofibroblasts are largely responsible for collagen and elastin deposition in the distal lung parenchyma (23), are thought to differentiate from interstitial fibroblasts, express high levels of $\alpha$ SMA (23), and likely play a critical role in alveolar development $(17,27)$. IUV caused a large and rapid increase in $\alpha$ SMA staining that was still present $7 \mathrm{~d}$ later, indicating that IUV stimulates increased $\alpha$ SMA expression due to increased proliferation and/or differentiation of fibroblasts into this phenotype. Increased numbers of differentiated myofibroblasts in response to IUV is consistent with increased elastin and collagen deposition and may contribute to the continued abnormal spatial pattern of collagen and elastin deposition $7 \mathrm{~d}$ later.

In summary, we have developed a unique model of VILI in the very immature lung that causes changes in lung morphol- 
ogy characteristic of acute and persistent lung injury in very preterm human infants. We have also shown that the reabsorption of immature secondary septal crests may contribute to the abnormal spatial pattern of elastin deposition and the larger, more simplified airsacs. Thus, selective reabsorption of immature secondary septal crests may contribute to abnormal lung development associated with BPD. As a result, VILI within the immature lung may stimulate abnormal lung development via increased and inappropriate cellular proliferation and differentiation and permanently destroy immature secondary septal crests leading to larger and more simplified distal airsacs.

Acknowledgments. We are indebted to Ms Alison Thiel, Ms Valerie Zahra, Mr Alex Satragno, and Ms Malgorzata Zieba for their expert technical assistance.

\section{REFERENCES}

1. Ikegami M, Kallapur S, Michna J, Jobe AH 2000 Lung injury and surfactant metabolism after hyperventilation of premature lambs. Pediatr Res 47:398-404

2. Attar MA, Donn SM 2002 Mechanisms of ventilator-induced lung injury in premature infants. Semin Neonatol 7:353-360

3. Coalson JJ 2003 Pathology of new bronchopulmonary dysplasia. Semin Neonatol 8:73-81

4. Dreyfuss D, Basset G, Soler P, Saumon G 1985 Intermittent positive-pressure hyperventilation with high inflation pressures produces pulmonary microvascular injury in rats. Am Rev Respir Dis 132:880-884

5. Albertine KH, Jones GP, Starcher BC, Bohnsack JF, Davis PL, Cho SC, Carlton DP, Bland RD 1999 Chronic lung injury in preterm lambs. Disordered respiratory tract development. Am J Respir Crit Care Med 159:945-958

6. Coalson JJ, Winter VT, Siler-Khodr T, Yoder BA 1999 Neonatal chronic lung disease in extremely immature baboons. Am J Respir Crit Care Med 160:1333-1346

7. Morton MJ, Pinson CW, Thornburg KL 1987 In utero ventilation with oxygen augments left ventricular stroke volume in lambs. J Physiol 383:413-424

8. Giraud GD, Morton MJ, Reid DL, Reller MD, Thornburg KL 1995 Effects of ductus arteriousus occlusion on pulmonary artery pressures during in utero ventilation in fetal sheep. Exp Physiol 80:129-139

9. Iwamoto HS, Teitel DF, Rudolph AM 1993 Effects of lung distension and spontaneous fetal breathing on hemodynamics in sheep. Pediatr Res 33:639-644
10. Nardo L, Maritz G, Harding R, Hooper SB 2000 Changes in lung structure and cellular division induced by tracheal obstruction in fetal sheep. Exp Lung Res 26:105-119

11. Hooper SB, Han VK, Harding R 1993 Changes in lung expansion alter pulmonary DNA synthesis and IGF-II gene expression in fetal sheep. Am J Physiol 265:L403L409

12. Joyce BJ, Wallace MJ, Pierce RA, Harding R, Hooper SB 2003 Sustained changes in lung expansion alter tropoelastin mRNA levels and elastin content in fetal sheep lungs. Am J Physiol Lung Cell Mol Physiol 284:L643-L649

13. Weibel ER, Gomez DM 1962 A principle for counting tissue structures on random sections. J Appl Physiol 17:343-348

14. Bancalari E, Claure N, Sosenko IR 2003 Bronchopulmonary dysplasia: changes in pathogenesis, epidemiology and definition. Semin Neonatol 8:63-71

15. Flecknoe SJ, Wallace MJ, Cock ML, Harding R, Hooper SB 2003 Changes in alveolar epithelial cell proportions during fetal and postnatal development in sheep. Am J Physiol Lung Cell Mol Physiol 285:L664-L670

16. Thibeault DW, Mabry S, Ekekezie II, Zhang X, Truog WE 2003 Collagen scaffolding during development and its deformation with chronic lung disease. Pediatrics 111:766-776

17. Pierce RA, Albertine KH, Starcher BC, Bohnsack JF, Carlton DP, Bland RD 1997 Chronic lung injury in preterm lambs: disordered pulmonary elastin deposition. Am J Physiol 272:L452-L460

18. McGowan SE 1992 Extracellular matrix and the regulation of lung development and repair. FASEB J 6:2895-2904

19. Wendel DP, Taylor DG, Albertine KH, Keating MT, Li DY 2000 Impaired distal airway development in mice lacking elastin. Am J Respir Cell Mol Biol 23:320-326

20. Coalson JJ, Winter VT, Gerstmann DR, Idell S, King RJ, DeLemos RA 1992 Pathophysiologic, morphometric, and biochemical studies of the premature baboon with bronchopulmonary dysplasia. Am Rev Respir Dis 145:872-881

21. Bland RD, Xu L, Ertsey R, Rabinovitch M, Albertine KH, Wynn KA, Kumar VH, Ryan RM, Swartz DD, Csiszar K, Fong KS 2007 Dysregulation of pulmonary elastin synthesis and assembly in preterm lambs with chronic lung disease. Am J Physiol Lung Cell Mol Physiol 292:L1370-L1384

22. Chambers RC, Laurent GJ 1996 The lung. In: Comper WD (ed) Extracellular Matrix. Amsterdam: Hardwood Academic Publishers, pp 378-409

23. Kaarteenaho-Wiik R, Paakko P, Herva R, Risteli L, Soini Y 2004 Type I and III collagen protein precursors and mRNA in the developing human lung. J Pathol 203:567-574

24. Shoemaker CT, Reiser KM, Goetzman BW, Last JA 1984 Elevated ratios of type I/III collagen in the lungs of chronically ventilated neonates with respiratory distress. Pediatr Res 18:1176-1180

25. Cherukupalli K, Larson JE, Rotschild A, Thurlbeck WM 1996 Biochemical, clinical, and morphologic studies on lungs of infants with bronchopulmonary dysplasia. Pediatr Pulmonol 22:215-229

26. Reid L, Rubino M 1959 The connective tissue septa in the foetal human lung. Thorax $14: 3-13$

27. Leslie KO, Mitchell JJ, Woodcock-Mitchell J, Low RB 1990 Alpha smooth muscle actin expression in developing and adult human lung. Differentiation 44:143-149 